\title{
Ultrastructural Analysis of the Surface of Endodontic Instruments after Immersion in Irrigating Solutions
}

\author{
Jelena Popović1, Goran Radenković, Jovanka Gašić1, Aleksandar Mitić1, Marija Nikolić1, \\ Radomir Barac ${ }^{1}$, Slavoljub Živković ${ }^{3}$ \\ 'University of Nišs, Medical Faculty, Clinic of Dentistry, Department of Restorative Dentistry and Endodontics, \\ Niš, Serbia; \\ ${ }^{2}$ University of Nišs, Mechanical Faculty, Department of Production Engineering, Niš, Serbia; \\ ${ }^{3}$ University of Belgrade, Faculty of Dental Medicine, Department of Restorative Dentistry and Endodontics, \\ Belgrade, Serbia
}

\begin{abstract}
SUMMARY
Introduction Separation (fracture) of endodontic instruments in the root canal during chemomechanical instrumentation is a complication that can compromise the final outcome of endodontic treatment. One of the most common factors that cause fatigue of endodontic instruments and consequent fracture is surface corrosion. The aim of this study was to investigate the ultrastructure of surface corrosion of endodontic instruments made of stainless steel and nickel-titanium after immersion in the most commonly used root canal irrigants.

Material and Methods The study included 48 nickel-titanium and stainless steel endodontic hand files. All instruments were immersed in $5.25 \%$ sodium hypochlorite, $0.2 \% \mathrm{CHX}$ and $17 \%$ EDTA. Surface corrosion was analyzed using a scanning electron microscope (SEM).

Results Nickel-titanium instruments showed significantly higher susceptibility to corrosion after immersion in $5.25 \%$ sodium hypochlorite compared to stainless steel instruments ( $p<0,001)$. After immersion in $0.2 \% \mathrm{CHX}$ corrosion damage was observed on both nickel-titanium and stainless steel instruments but the difference was not statistically significant $(p=0.096)$. No corrosion was observed in both types of instruments after immersion in 17\% EDTA.

Conclusion The use of $5.25 \% \mathrm{NaOCl}$ and $0.2 \% \mathrm{CHX}$ as root canal irrigating solutions can cause serious corrosion changes on the surface of nickel-titanium and stainless steel endodontic instruments.

Keywords: corrosion; endodontic instruments; nickel-titanium; stainless steel; SEM
\end{abstract}

\section{INTRODUCTION}

Endodontic instrument separation (fracture) in the root canal during chemomechanical preparation is a complication that can compromise the final outcome of endodontic therapy [1]. Weakening of instruments' structure is one of important factors that affect safety of their use. Numerous studies that have examined clinical use of endodontic instruments have concluded that metal fatigue is the first anomaly which occurs during clinical use and that, combined with sudden loads during root canal instrumentation, may lead to fracture $[1,2]$. In addition, the literature data indicate surface corrosion of endodontic instruments as one of the first factors that can cause fatigue of the material [3]. Corrosion can start during chemomechanical instrumentation or chemical disinfection and sterilization of instruments [1]. Corrosion is caused by the contact of metal with different solutions when various electrochemical reactions occur and affect surface integrity making instruments more prone to fracture [4]. Corrosion pits and surface porosity can also reduce the cutting efficiency of endodontic instruments [5].
The aim of this study was to evaluate the ultrastructure of surface corrosion of stainless steel and nickel-titanium endodontic files after immersion in the most commonly used root canal irrigants.

\section{MATERIAL AND METHODS}

The study included nickel-titanium (Ni-Ti) („I-FLEX“, „IMD“, USA) and stainless steel (NTI-Kahla GmbH, Germany) hand endodontic files. New instruments were taken out of the packages, and in order to remove all debris received from manufacturers, the files were cleaned in the ultrasonic bath (JUS-S01, JEOL) with distilled water for 15 minutes at the frequency of $28 \mathrm{kHz}$. Then after, the corrosion behaviour of endodontic instruments was assessed using potentiodynamic metod in the three most commonly used irrigating solutions: $5.25 \%$ sodium hypochlorite $(\mathrm{NaOCl})$ (prepared in the laboratory); $0.2 \%$ chlorhexidine gluconate (CHX) (R4, Septodont, France, diluted to $0.2 \%) ; 17 \%$ ethylenediamine tetraacetic acid (EDTA) (prepared in the laboratory). 
Table 1. Endodontic instruments according to the material and irrigating solution

Tabela 1. Podela ispitivanih instrumenata u odnosu na vrstu materijala i rastvor za irigaciju

\begin{tabular}{|l|c|c|c|c|c|}
\hline \multirow{2}{*}{$\begin{array}{l}\text { Material } \\
\text { Materijal }\end{array}$} & \multicolumn{3}{|c|}{$\begin{array}{c}\text { Irrigating solution } \\
\text { Rastvor za irigaciju }\end{array}$} & $\begin{array}{c}\text { Control } \\
\text { Kontrola }\end{array}$ & $\begin{array}{c}\text { Total } \\
\text { Ukupno }\end{array}$ \\
\cline { 2 - 6 } & $\mathrm{NaOCl}$ & CHX & EDTA & 6 & 24 \\
\hline $\begin{array}{l}\mathrm{Ni}-\mathrm{Ti} \\
\mathrm{Ni}-\mathrm{TI}\end{array}$ & 6 & 6 & 6 & 6 & 6 \\
\hline $\begin{array}{l}\text { Stainless steel } \\
\text { Nerđajući čelik }\end{array}$ & 6 & 6 & 6 & 6 & 24 \\
\hline $\begin{array}{l}\text { Total } \\
\text { Ukupno }\end{array}$ & 12 & 12 & 12 & 12 & 48 \\
\hline
\end{tabular}

$\mathrm{Ni}$-Ti - nickel-titanium; $\mathrm{NaOCl}$ - sodium hypochlorite (5.25\%); $\mathrm{CHX}$ - chlorhexidine gluconate (0.2\%); EDTA - ethylenediamine tetraacetic acid (17\%)

$\mathrm{Ni}$-Ti - nikl-titanijum; $\mathrm{NaOCl}$ - natrijum-hipohlorit (5,25\%); $\mathrm{CHX}$ - hlorheksidinglukonat (0,2\%); EDTA - etilendiaminotetrasirćetna kiselina (17\%)

All solutions used in this study were freshly prepared and stored in adequate conditions.

Forty-eight instruments (24 Ni-Ti and 24 stainless steel instruments) were tested. Instruments were divided into the 6 groups according to the material and used irrigating solution (Table 1).

The experiments were carried out in an ordinary, threecompartment cylindrical glass cell. The counter electrode was a Pt foil and the reference electrode was a saturated calomel electrode (SCE). All potentials were referred to SCE. The working electrode- endodontic instrument was placed into the cell in such way that only working part of the instrument was immersed in the solution, whereas the handle was above the solution. The instruments were immersed 15 seconds before the potential rise as set by the software. Anodic E-I polarization curves were recorded using the software Par Stat by means of the linear sweep technique (sweep rate $0.2 \mathrm{mV} / \mathrm{s}$ ). The potential value that showed sharp rise of the current was assigned as pitting potential. The sharp increase of the current was a result of local dissolution of metal and forming pits. Electrochemical testing was performed at the Department of Production Engineering, Faculty of Mechanical Engineering, University of Niš, and Department of Physical Chemistry and Electrochemistry, Faculty of Technology and Metallurgy, University of Belgrade.

After electrochemical testing (published results) [6], the instruments were prepared for scanning electron microscopic examination (SEM; JEOL-JSM 5300). In order to obtain adequate visualization of the working parts of instruments, the handles of the instruments were cut off, and their working parts were fixed to the aluminum stubs with a fixing agent (Dotite paint xc 12 Carbon JEOL, Tokyo, Japan) and sputter coated with gold/palladium (in the unit JFC 110 Ion Sputter JEOL). SEM examination was completed at the Institute for Biomedical Research of the Faculty of Medicine in Nis.

Ultrastructure of the surface corrosion changes was analysed using modified score presented by Linsuwanont et al. [7]: score 3 - continuous corrosion of the entire surface of the instrument; score 2 - clearly limited corrosion fields; score 1 - individual corrosion pits; score 0 - no visible corrosion changes. Surface of the working parts of the instruments was observed at three levels: apical, middle and coronal. At each level an appropriate score was estimated, and final score represented the mean value of all three scores for each instrument individually and also within the groups.

Statistical analysis was performed using $\chi^{2}$ and Fisher Exact test, a $p$ value of $p<0.05$ was considered statistically significant.

\section{RESULTS}

Ultrastructural analysis of instruments surfaces showed the most intensive corrosion changes on the Ni-Ti instruments after immersion in 5.25\% sodium hypochlorite. Erosive metal surfaces were observed along the entire working part of all tested instruments in this group (score 3) (Table 2, Figures 1 and 2). Sensitivity to $5.25 \% \mathrm{NaOCl}$ was also seen in stainless steel instruments. Continuous surface corrosion and limited fields of corrosion were observed on the working surfaces of these instruments, so the total score of this group was 2.33 (Table 2, Figure 3). Fisher Exact test showed significantly higher sensitivity of Ni-Ti instruments compared to stainless steel after immersion in $5.25 \%$ sodium hypochlorite $(\mathrm{p}<0.001)$.

SEM analysis of the Ni-Ti instruments after immersion in $0.2 \%$ CHX showed limited corrosion fields and individual corrosion pits. The total score in this group of instruments was 1.5 (Table 2, Figures 4 and 5). Stainless steel instruments showed higher vulnerability to $0.2 \%$ CHX. These instruments had higher number of limited corrosion fields compared to individual corrosion pits, so the total score in this group was 1.83 (Table 2, Figure 6). However, Fisher Exact test did not show statistically significant difference in sensitivity to $0.2 \% \mathrm{CHX}$ between both types of instruments ( $\mathrm{p}=0.096$ ).

Ultrastructural analysis of Ni-Ti instruments after immersion in 17\% EDTA did not show corrosion defects on the surface of working parts of the instruments so this group was assigned score 0 (Table 2, Figure 7). Corrosion damages were not observed on the surfaces of the stainless steel instruments after immersion in 17\% EDTA, so the average score for this group was also 0 (Table 2, Figure 8).

Nickel-titanium and stainless steel instruments showed different susceptibility to the tested irrigating solutions. Nickel-titanium instruments showed significantly higher susceptibility to $5.25 \%$ sodium hypochlorite compared to

Table 2. Average score of corrosion defects on instruments after immersion in endodontic irrigants

Tabela 2. Prosečan skor korozivnih oštećenja na instrumentima posle potapanja u rastvore za irigaciju

\begin{tabular}{|l|c|c|c|c|}
\hline \multirow{2}{*}{$\begin{array}{l}\text { Material } \\
\text { Materijal }\end{array}$} & \multicolumn{3}{|c|}{$\begin{array}{c}\text { Irrigating solution } \\
\text { Rastvor za irigaciju }\end{array}$} & \multirow{2}{*}{$\begin{array}{c}\text { Control } \\
\text { Kontrola }\end{array}$} \\
\cline { 2 - 4 } & $\mathrm{NaOCl}$ & $\mathbf{C H X}$ & EDTA & \\
\hline $\begin{array}{l}\mathrm{Ni}-\mathrm{Ti} \\
\mathrm{Ni}-\mathrm{Ti}\end{array}$ & 3 & 1.5 & 0 & 0 \\
\hline $\begin{array}{l}\text { Stainless-steel } \\
\text { Nerđajući čelik }\end{array}$ & 2.33 & 1.83 & 0 & 0 \\
\hline
\end{tabular}




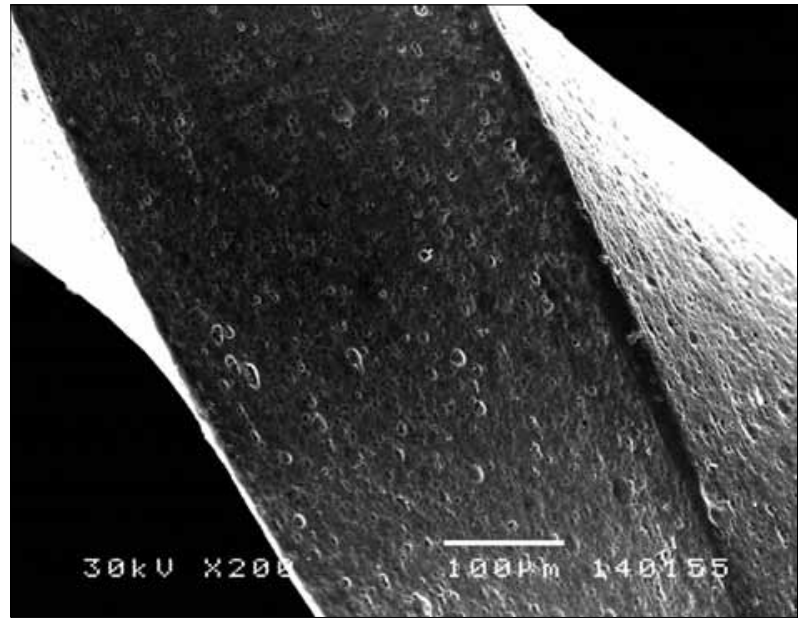

Figure 1. Continuous corrosion damage of the nickel-titanium ( $\mathrm{Ni}-\mathrm{Ti})$ instrument surface after immersion in $5.25 \%$ sodium hypochlorite $(\mathrm{NaOCl})$

Slika 1. Kontinuirano korozivno oštećenje površine instrumenta od nikl-titanijuma ( $\mathrm{Ni}$-Ti) posle potapanja u rastvor natrijum-hipohlorita $(\mathrm{NaOCl})$ u koncentraciji od 5,25\%

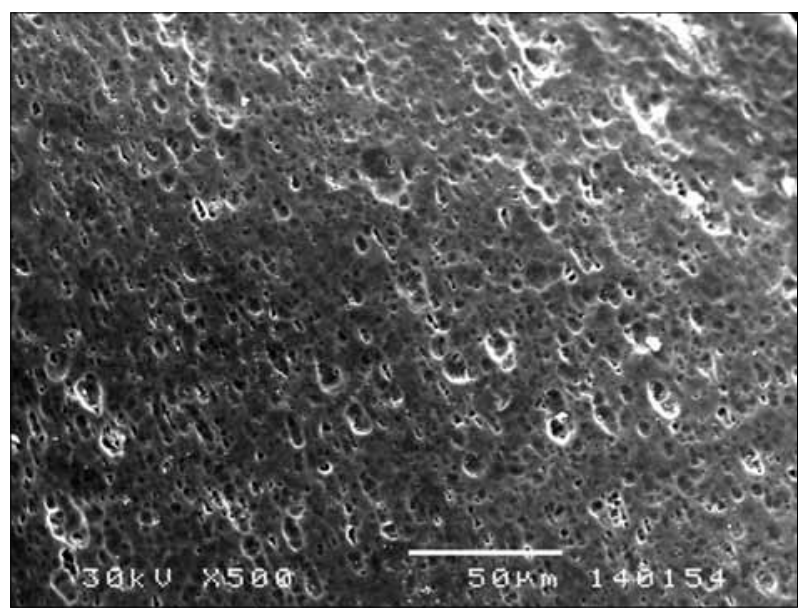

Figure 2. Surface errosion of the $\mathrm{Ni}$-Ti instruments after immersion in $5.25 \% \mathrm{NaOCl}$ at $\times 500$ magnification

Slika 2. Površinska erozija $\mathrm{Ni}-\mathrm{Ti}$ instrumenta posle potapanja u $5,25 \% \mathrm{NaOCl}$ pri uvećenju od $\times 500$

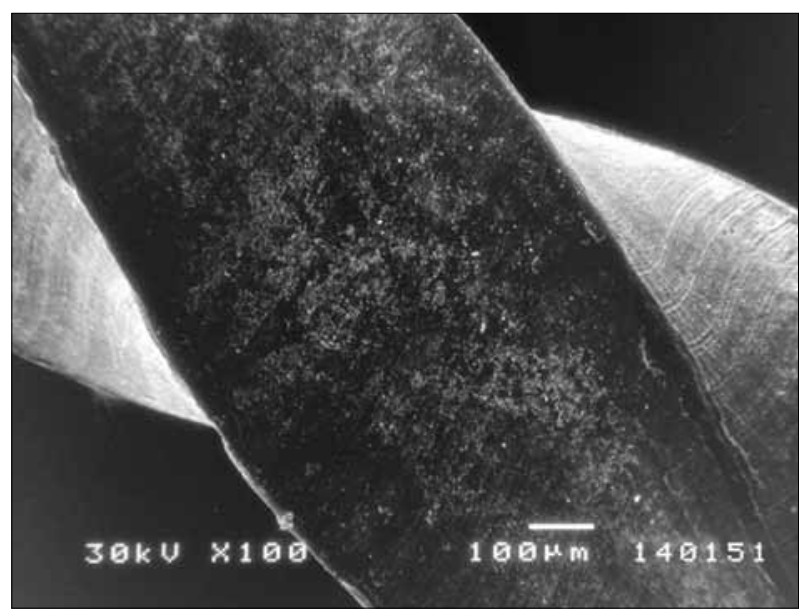

Figure 3. Continuous surface corrosion of the stainless steel instrument after immersion in $5.25 \% \mathrm{NaOCl}$

Slika 3. Kontinuirana korozivna površina instrumenta od nerđajućeg čelika posle potapanja u $5,25 \% \mathrm{NaOCl}$

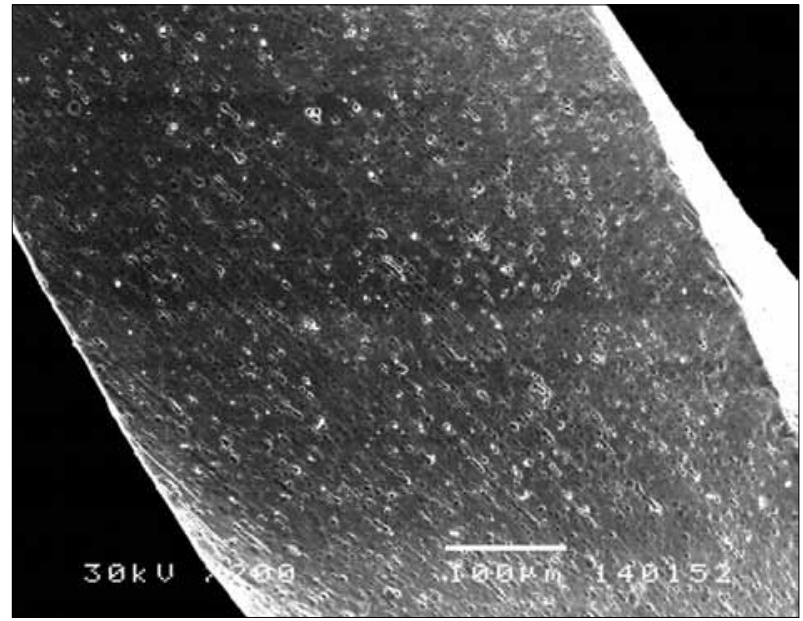

Figure 4. Limited corrosion fields and individual corrosion pits on the surface of the $\mathrm{Ni}-\mathrm{Ti}$ instrument after immersion in $0.2 \%$ chlorhexidine gluconate $(\mathrm{CHX})$

Slika 4. Ograničena korozivna polja i pojedinačne korozivne jamice na površini $\mathrm{Ni}-\mathrm{Ti}$ instrumenta posle potapanja u rastvor hlorheksidin-glukonata $(\mathrm{CHX})$ u koncentraciji od 0,2\%

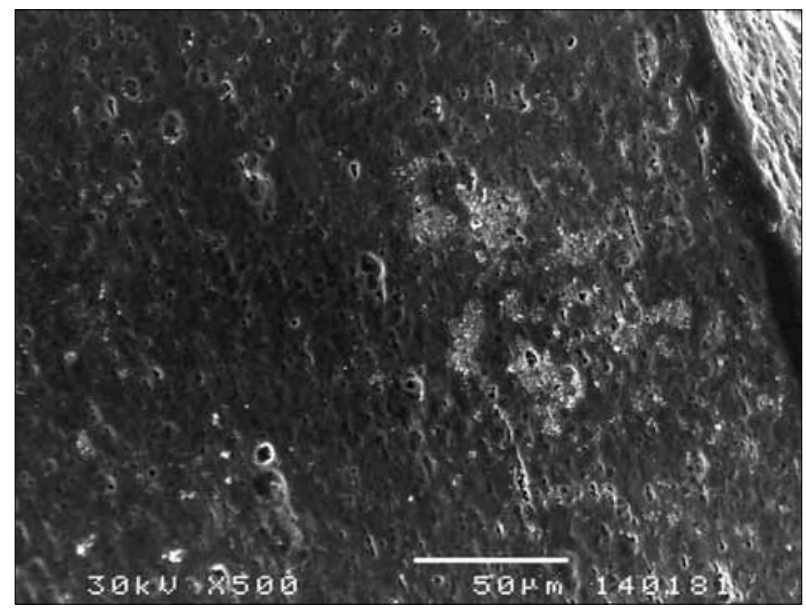

Figure 5. Limited corrosion fields and individual corrosion pits on the surface of the Ni-Ti instrument after immersion in $0.2 \% \mathrm{CHX}$ at higher magnification

Slika 5. Ograničena korozivna polja i pojedinačne korozivne jamice na površini $\mathrm{Ni}-\mathrm{Ti}$ instrumenta posle potapanja u $0,2 \% \mathrm{CHX}$ na većem uvećanju

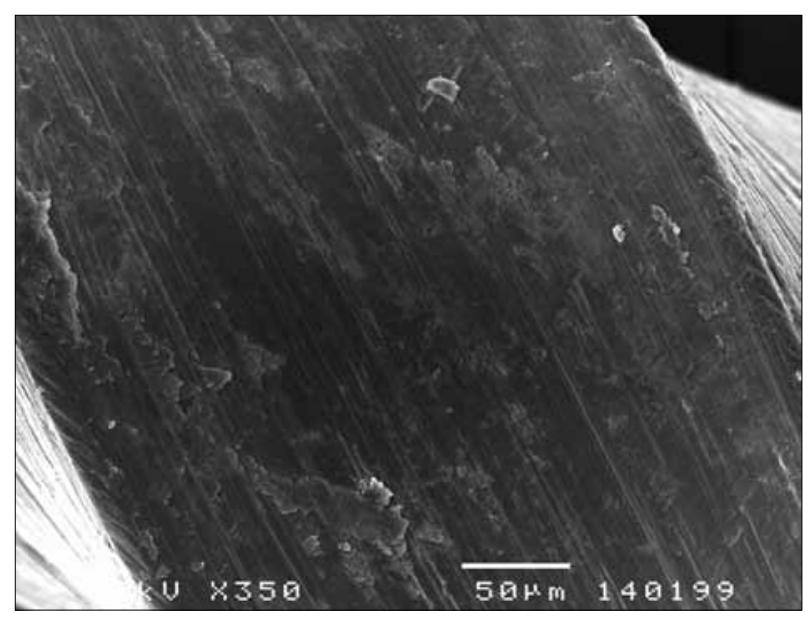

Figure 6. Corrosion in the form of restricted fields on the stainless steel instrument after immersion in $0.2 \% \mathrm{CHX}$

Slika 6. Korozija u vidu ograničenih polja na instrumentu od nerđajućeg čelika posle potapanja u $0,2 \% \mathrm{CHX}$ 


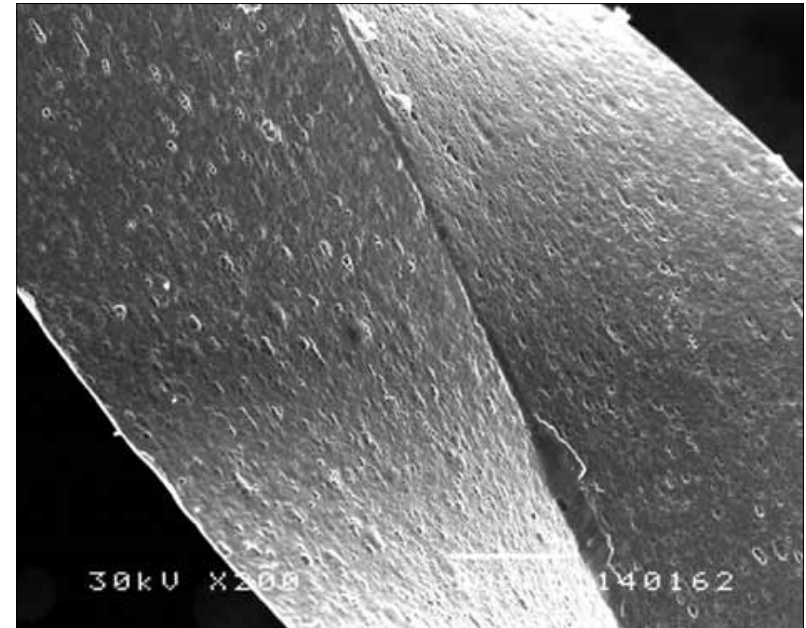

Figure 7. Surface structure of the Ni-Ti instrument after immersion in $17 \%$ ethylenediamine tetraacetic acid (EDTA)

Slika 7. Površinska struktura Ni-Ti instrumenta posle potapanja u etilendiaminotetrasirćetnu kiselinu (EDTA) u koncentraciji od 17\%

$0.2 \% \mathrm{CHX}, \chi^{2}$ test showed that this difference was highly statistically significant $(\mathrm{p}<0.001)$. Stainless steel instruments also showed statistically higher sensitivity to immersion in $5.25 \%$ sodium hypochlorite compared to $0.2 \%$ CHX (p<0.05).

\section{DISCUSSION}

Chemomechanical instrumentation of the root canal is essential during endodontic treatment and involves procedures of cleaning and shaping of the root canal space and use of irrigating solutions. Most commonly used irrigation solutions are: sodium hypochlorite $(\mathrm{NaOCl})$, hydrogen peroxide $\left(\mathrm{H}_{2} \mathrm{O}_{2}\right)$, citric acid, ethylenediamine tetraacetic acid (EDTA), chlorhexidine gluconate (CHX), saline solution, etc [5]. Although the use of irrigants during root canal preparation is essential, chemical and electrochemical aggressiveness of these solutions can damage surface of the instruments [8].

Electrochemical techniques based on determination of pitting potential and current density can accurately define sensitivity of metals to different solutions [9]. The surface ultrastructure also plays an important role in determining corrosion behaviour of the tested endodontic instruments in certain solutions [10]. Corrosion on the microscopic level is directly related to the weakening of the structure of instruments that reduces cutting efficiency and make instruments more susceptible to fracture [9].

Corrosion behaviour of nickel-titanium and stainless steel instruments can be affected by numerous factors. Stokes et al. [11] investigated corrosive effect on Ni-Ti instruments of five different manufacturers. They reported that both corroding and non-corroding files were present in the same packages and these results confirmed that severity of corrosion could depend on manufacturing process and quality control. The negative impact of sterilization on corrosion has also been demonstrated [10]. The presence of residual protein substances on the surface of

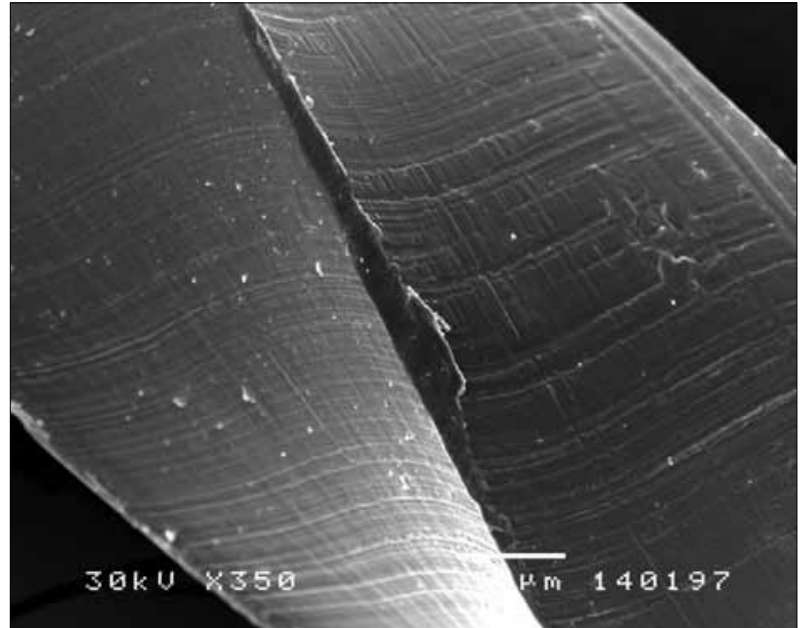

Figure 8. Surface of the stainless steel instrument after immersion in $17 \%$ EDTA

Slika 8. Površina instrumenta od nerđajućeg čelika posle potapanja u $17 \%$ EDTA

endodontic instruments can also increase the severity of surface attack and dissolution of metal surface [9].

Sodium hypochlorite $(\mathrm{NaOCl})$ is the most commonly used solution for root canal irrigation in endodontic practice. It is used in concentration range from $0.5 \%$ to $6 \%$ [12]. It has a wide spectrum of antimicrobial activity, and due to its ability to dissolve organic part of dentin it is used for removing smear layer as well as pre-soaking solution in the cleaning procedures after clinical use [13, 14]. However, sodium hypochlorite contains active and aggressive $\mathrm{Cl}^{-}$ions that promote the occurrence of corrosion pits and weakening of the instrument structure [15]. It has been shown that $\mathrm{NaOCl}$ is corrosive for many metals and selectively removes nickel from Ni-Ti alloys [16]. Studies have shown measurable release of titanium after immersion of Ni-Ti instruments in $\mathrm{NaOCl}$ for 30 to 60 minutes [17]. Sensitivity of nickel-titanium and stainless steel endodontic instruments to $\mathrm{NaOCl}$ has been reported in numerous studies $[1,5,13]$. In the study of Stokes et al. [14] corrosion of endodontic instruments was visually confirmed after immersion in $5.25 \% \mathrm{NaOCl}$. A significant difference between different manufacturers was observed, but there were no significant differences between nickeltitanium and stainless steel instruments. Berutti et al. [4] found that instruments immersed in $\mathrm{NaOCl}$ had significantly reduced resistance to fracture due to early cycle fatigue and occurrence of unexpected fractures in these instruments was significantly higher than in the control group of instruments. SEM analysis of the fractured surface revealed limited corrosion fields, pits and cracks. The effect of $\mathrm{Cl}^{-}$and $\mathrm{F}^{-}$ions on the corrosion of $\mathrm{Ni}-\mathrm{Ti}$ and stainless steel was studied by Amaral et al. [18] and Aboud et al. [19] for the purpose of electrochemical dissolution and removal of fractured endodontic instruments from root canals. The current study revealed intensive continuous corrosion damages of instruments after immersion in $5.25 \%$ sodium hypochlorite and this was in accordance with pitting potential values obtained in electrochemical analysis [6]. 
Chlorhexidine gluconate (CHX) represent frequently used root canal irrigant due to its prolonged antimicrobial effect that may last up to 12 weeks [20]. It is used in a concentration range from $0.1 \%$ to $2 \%$. However, literature data indicate the potential for surface corrosion of instruments after immersion in CHX [5, 6]. Corrosion potential of $\mathrm{CHX}$ depends on its acidic $\mathrm{pH}$ (5.72) as acidic environment increases the corrosion rate [21]. In the current study, a visibly damage of the surface of $\mathrm{Ni}-\mathrm{Ti}$ and stainless steel instruments was observed after immersion in $0.2 \%$ CHX. Such visible damage in the form of limited fields and fissures can act as weak points where further loads on instruments can lead to undesirable cracks that propagate [8].

Ethylenediamine tetraacetic acid (EDTA) is a chelating agent that is used in endodontic practice at concentrations from $15 \%$ to $17 \%$. Due to its ability to dissolve inorganic part of dentin, it is used as a lubricant in the preparation of narrow and curved root canals and for removal of inorganic part of the smear layer [22]. The results of SEM analysis from the current study revealed no negative effects of EDTA on the surface structure of $\mathrm{Ni}$-Ti and stainless steel instruments, and that was in accordance with the results of electrochemical testing from previous study [6]. In a study published by Fayyad and Mahran [23] there was no visible change in surface roughness of endodontic instruments after immersion in 17\% EDTA. According to Reinhard et al. [24] EDTA has the ability to protect and passivize instruments because it forms complexes with metal ions at $\mathrm{pH}$ values less than 4 thus creating an inhibiting barrier for oxidation and corrosion.

\section{CONCLUSION}

The use of $5.25 \% \mathrm{NaOCl}$ and $0.2 \% \mathrm{CHX}$ as root canal irrigants may cause serious corrosion damage on the surface of $\mathrm{Ni}$-Ti and stainless steel endodontic instruments. The application of 17\% EDTA did not cause corrosion changes in both types of instruments. To minimize the risk of damage it is recommended that irrigants should be rinsed out from the files immediately after their use and files should be replaced frequently.

\section{NOTE}

The paper was given as poster presentation at the Rosov Pin 2014, The Second Regional Roundtable: Refractory, Process Industry and Nanotechnology, held on October 23-24, 2014 in Fruška gora.

\section{REFERENCES}

1. Darabara M, Bourithis L, Zinelis S, Papadimitriou GD. Susceptibility to localized corrosion of stainless steel and NiTi endodontic instruments in irrigating solutions. Int Endod J. 2004; 37:705-10. [DOI: 10.1111/j.1365-2591.2004.00866.x] [PMID: 15347296]
2. Zinelis S, Margelos J. Failure mechanism of Hedstroem endodontic files in vivo. J Endod. 2002; 28:471-3. [DOI: 10.1097/00004770-200206000-00014] [PMID: 12067133]

3. Sotokawa T. An analysis of clinical breakage of root canal instruments. J Endod. 1988; 14:75-82. [DOI: 10.1016/S0099-2399(88)80005-0] [PMID: 3162943$]$

4. Berutti E, Angelini E, Rigolone M, Migliaretti G, Pasqualini D. Influence of sodium hypochlorite on fracture properties and corrosion of ProTaper rotary instruments. Int Endod J. 2006; 39:693-9. [DOI: 10.1111/j.1365-2591.2006.01134.x] [PMID: 16916358]

5. Öztan DM, Akman AA, Zaimoglu L, Bilgiç S. Corrosion rates of stainless-steel files in different irrigating solutions. Int Endod J. 2002; 35:655-9. [DOI: 10.1046/j.1365-2591.2002.00530.x] [PMID: 12196218]

6. Popović J, Radenković G, Gašić J, Živković S, Mitić A, Nikolić M, et al. The examination of sensitivity to corrosion of nickel-titanium and stainless steel endodontic instruments in root canal irrigating solutions. Chemical Industry and Chemical Engineering Quarterly. [in press] [DOI: 10.2298/CICEQ150103023P]

7. Linsuwanont P, Parashos P, Messer HH. Cleaning of rotary nickeltitanium endodontic instruments. Int Endod J. 2004; 37:19-28. [DOI: 10.1111/j.1365-2591.2004.00747.x] [PMID: 14718053]

8. Saglam BC, Kocak S, Kocak MM, Topuz O. Effects of irrigating solutions on the surface of ProTaper instruments: a microscopy study. Microsc Res Tech. 2012; 75:1534-8. [DOI: 10.1002/jemt.22097] [PMID: 22791665]

9. Mueller HJ. Corrosion determination techniques applied to endodontic instruments - irrigation solution systems. J Endod. 1982; 8:246-52. [DOI: 10.1016/S0099-2399(82)80334-8] [PMID: 6955425]

10. Casella G, Rosalbino F. Corrosion behaviour of NiTi endodontic instruments. Corros Eng Sci Techn. 2011; 46:521-3. [DOl: 10.1179/147842209X12559428167445]

11. Stokes WO, Di Fiore MP, Barss TJ, Koerber A, Gilbert LJ, Lautenschlager PE. Corrosion in Stainless-Steel and Nickel-Titanium Files. J Endod. 1999; 25:17-20. [DOI: 10.1016/ S0099-2399(99)80392-6] [PMID: 10196837]

12. Heling I, Rotstein I, Dinur T, Szwec-Levine Y, Steinberg D. Bactericidal and cytotoxic effects of sodium hypochlorite and sodium dichloroisocyanurate solutions in vitro. J Endod. 2001; 27:278-80. [DOI: 10.1097/00004770-200104000-00009] [PMID: 11485267]

13. O'Hoy PYZ, Messer HH, Palamara JEA. The effect of cleaning procedures on fracture properties and corrosion of NiTi files. Int Endod J. 2003; 36:724-32. [DOI: 10.1046/j.1365-2591.2003.00709.x] [PMID: 14641435]

14. Stojicic S, Zivkovic S, Qian W, Zhang H, Haapasalo M. Tissue dissolution by sodium hypochlorite: Effect of concentration, temperature, agitation, and surfactant. . Endod. 2010; 36:1558-62. [DOI: 10.1016/j. joen.2010.06.021] [PMID: 20728727]

15. Katayama H, Yamamoto M, Kodama T. Degradation behavior of protective rust layer in chloride solutions. Corrosion Engineering. 2000; 49:41-4. [DOl: 10.3323/ jcorr1991.49.41]

16. Sarkar NK, Redmond W, Schwaninger B, Goldberg AJ. The chloride corrosion behaviour of four orthodontic wires. I Oral Rehabil. 1983; 10:121-8. [DOI: 10.1111/ j.1365-2842.1983.tb00106.x] [PMID: 6573461]

17. Busslinger A, Sener B, Barbakow F. Effects of sodium hypochlorite on nickel-titanium Lightspeed ${ }^{\circ}$ instruments. Int Endod J. 1998; 31:290-4. [DOI: 10.1046/j.1365-2591.1998.00149.x] [PMID: 9823119]

18. Amaral CCF, Ormiga F, Gomes JACP. Electrochemical-induced dissolution of stainless steel files. Int Endod J. 2015; 48:137-44. [DOl: 10.1111/iej.12292] [PMID: 24702197]

19. Aboud LRL, Ormiga F, Gomes JACP. Electrochemical induced dissolution of fragments of nickel-titanium endodontic files and their removal from simulated root canals. Int Endod J. 2014; 47:155-62. [DOI: 10.1111/iej.12126] [PMID: 23659794]

20. Gasic J, Popovic J, Zivkovic S, Petrovic A, Barac R, Nikolic M. UItrastructural analysis of the root canal walls after simultaneous irrigation of different sodium hypochlorite concentration and 0,2\% chlorhexidine gluconate. Microsc Res Techniq. 2012; 75:1099-103. [DOI: 10.1002/jemt.22036] [PMID:22419366]

21. Matamala GR . Correlation model of the AISI 316 stainless steel pitting potential with cellulose bleach process variables. Corrosion. 1987; 43:97-100. [DOI: 10.5006/1.3583124] 
22. Hülsmann $M$, Heckendorff $M$, Lennon $A$. Chelating agents in root canal treatment: mode of action and indications for their use. Int Endod J. 2003; 36:810-30. [DOI: 10.1111/j.1365-2591.2003.00754.x] [PMID: 14641420]

23. Fayyad DM, Mahran AH. Atomic force microscopic evaluation of nanostructure alterations of rotary NiTi instruments after immersion in irrigating solutions. Int Endod J. 2014; 47:567-73.

[DOI: 10.1111/iej.12189] [PMID:24138190]
24. Reinhard G, Radtke M, Rammelt $U$. The role of the salts of weak acids in the chemical passivation of iron and steel in aqueous. Corrosion Sci. 1992; 33:307-13. [DOI: 10.1016/0010-938X(92)90154-U]

Received: 01/07/2015 - Accepted: 10/10/2015 


\title{
Ultrastrukturna analiza površine endodontskih instrumenata nakon potapanja u rastvore za irigaciju
}

\author{
Jelena Popović1, Goran Radenković , Jovanka Gašić1, Aleksandar Mitić1, Marija Nikolić1, \\ Radomir Barac' ${ }^{1}$, Slavoljub Živković ${ }^{3}$ \\ 'Univerzitet u Nišu, Medicinski fakultet, Klinika za stomatologiju, Odeljenje za bolesti zuba i endodonciju, Niš, Srbija; \\ ${ }^{2}$ Univerzitet u Nišu, Mašinski fakultet, Katedra za proizvodno-informacione tehnologije i menadžment, Niš, Srbija; \\ ${ }^{3}$ Univerzitet u Beogradu, Stomatološki fakultet, Klinika za bolesti zuba i endodonciju, Beograd, Srbija
}

\begin{abstract}
KRATAK SADRŽAJ
Uvod Fraktura endodontskih instrumenata u kanalu korena tokom hemomehaničke preparacije je značajna komplikacija koja može ugroziti konačan ishod endodontskog lečenja. Jedan od važnih faktora koji izazivaju zamor materijala endodontskog instrumenta je površinska korozija. Cilj ovog rada je bio da se ispita ultrastruktura površine endodontskih instrumenata od nerđajućeg čelika i nikl-titanijuma nakon potapanja u najčešće upotrebljavane rastvore za irigaciju kanala korena zuba.

Materijal i metode rada $U$ istraživanju je korišćeno 48 instrumenata od nikl-titanijuma i nerđajućeg čelika. Testiranje osetljivosti na koroziju je izvršeno potapanjem u rastvore $\mathrm{NaOCl}$ od 5,25\%, CHX od 0,2\% i EDTA od 17\%. Analiza korozivnih oštećenja je urađena pomoću skening elektronskog mikroskopa (SEM) na različitim uveličanjima.

Rezultati Instrumenti od nikl-titanijuma su pokazali statistički značajno veću osetljivost na koroziju nakon potapanja u 5,25\% $\mathrm{NaOCl}$ u poređenju sa instrumentima od nerđajućeg čelika $(p<0,001)$. Nakon potapanja u $0,2 \% \mathrm{CHX}$ uočeno je korozivno oštećenje instrumenata od nikl-titanijuma i nerđajućeg čelika, ali razlika nije bila statistički značajna. Korozija nakon potapanja u 17\% EDTA nije uočena ni kod jedne vrste endodontskih instrumenata.

Zaključak Primena 5,25\% NaOCl i 0,2\% CHX kao rastvora za irigaciju kanala korena može izazvati ozbiljne korozivne promene na površini instrumenata od nikl-titanijuma i nerđajućeg čelika.

Ključne reči: korozija; endodontski instrumenti; nikl-titanijum; nerđajući čelik; SEM
\end{abstract}

\section{UVOD}

Fraktura endodontskih instrumenta u kanalu korena tokom hemomehaničke preparacije je komplikacija koja može ugroziti konačan ishod endodontskog lečenja [1]. Slabljenje strukture instrumenata je jedan od bitnih faktora koji utiču na bezbednost njihove upotrebe u preparaciji kanala korena zuba. Brojne studije koje su se bavile kliničkom upotrebom endodontskih instrumenata pokazale su da je zamor materijala prva nepravilnost koja se javlja u kliničkim uslovima i koja, udruženo sa naglim opterećenjima tokom preparacije, može dovesti do preloma [1, 2]. Podaci iz literature takođe ukazuju na to da je pojava površinske korozije endodontskih instrumenata jedan od prvih faktora koji uslovljavaju zamor materijala endodontskog instrumenta [3]. Korozija se može javiti tokom hemomehaničke preparacije, hemijske dezinfekcije i sterilizacije endodontskih instrumenata [1]. Mogući fenomen korozije izazvan kontaktom endodontskih instrumenata sa brojnim rastvorima dovodi do različitih elektrohemijskih reakcija i utiče na integritet površine instrumenata, čineći ih time, u uslovima kritičnog zamora, podložnim lomljenju [4]. Istraživanja su pokazala da korozivne jamice i poroznost površine na radnom delu endodontskog instrumenta u velikoj meri mogu smanjiti i njihovu sečivnu efikasnost [5].

Cilj ovog rada je bio da se ispita ultrastruktura korozivne površine endodontskih instrumenata od nerđajućeg čelika i nikltitanijuma (Ni-Ti) nakon potapanja u najčešće upotrebljavane rastvore za irigaciju kanala korena zuba.

\section{MATERIJAL I METODE RADA}

$\mathrm{U}$ istraživanju su korišćeni ručni endodontski instrumenti od Ni-Ti („I-FLEX“, „IMD“, SAD) i nerđajućeg čelika (NTI-Kahla
$G m b H$, Nemačka). Novi instrumenti su uzimani iz pakovanja proizvođača i, radi uklanjanja ostataka proizvodnog debrisa, očišćeni u ultrazvučnom kupatilu (JUS-S01, JEOL) destilovanom vodom u trajanju od 15 minuta na frekvenciji od $28 \mathrm{kHz}$. Nakon toga instrumenti su podvrgnuti potenciodinamičkom ispitivanju korozije u tri najčešće upotrebljavana rastvora za irigaciju kanala korena.

U istraživanju su korišćeni sledeći rastvori: natrijum-hipohlorit $(\mathrm{NaOCl}) \mathrm{u}$ koncentraciji od $5,25 \%$ (pripremljen $\mathrm{u}$ laboratoriji), hlorheksidin-glukonat (CHX) u koncentraciji od 0,2\% (R4, Septodont, Francuska, rastvoren do 0,2\%) i etilendiaminotetrasirćetna kiselina (EDTA) u koncentraciji od 17\% (pripremljena u laboratoriji). Rastvori su bili sveže pripremljeni i čuvani u odgovarajućim uslovima.

$\mathrm{U}$ istraživanju je analizirano ukupno 48 instrumenata: 24 od Ni-Ti i 24 od nerđajućeg čelika. Instrumenti su svrstani u tri grupe od po šest instrumenata u odnosu na vrstu irigansa, dok je preostalih šest instrumenata služilo kao kontrola (Tabela 1).

Eksperiment je izveden u uobičajenoj trodelnoj cilindričnoj staklenoj ćeliji sa dve elektrode. Suprotna elektroda je bila od platine, a referentnu elektrodu je činila zasićena kalomelova elektroda (SCE). Vrednosti potencijala su izražene u odnosu na SCE. Endodontski instrument je predstavljao radnu elektrodu i njegov radni deo je uranjan u ispitivani rastvor, dok su osovina instrumenta i ručica bili iznad nivoa rastvora. Vreme od 15 sekundi, koliko je instrument stajao u rastvoru do početka rasta potencijala, bilo je programski podešeno. Anodne polarizacione krive su snimane korišćenjem softvera Par Stat sa promenom potencijala od $0,2 \mathrm{mV} / \mathrm{s}$. Vrednost potencijala pri kojem je dolazilo do naglog porasta gustine struje označeno je kao potencijal pitinga. Porast struje je bio posledica lokalnog rastvaranja metala i početka formiranja tačkica, koje su pri porastu struje i potencija rasle prvenstveno u dubinu. Ispitivanje je obavljeno 
na Katedri za proizvodno-informacione tehnologije Mašinskog fakulteta Univerziteta u Nišu i na Katedri za fizičku hemiju Tehnološko-metalurškog fakulteta Univerziteta u Beogradu.

Nakon elektrohemijskih ispitivanja (objavljeni rezultati) [6], instrumenti su pripremani za skening-elektronmikroskopsko ispitivanje. Da bi se uzorci adekvatno pozicionirali i pričvrstili za cilindrične nosače, osovina i ručica endodontskih instrumenata su odsečene kleštima, a radni delovi sa sečivima i navojima pričvršćeni sredstvom za fiksiranje (Dotite paint xc 12 Carbon $J E O L$, Tokio, Japan) za cilindrične nosače, a potom naparavani solima zlata u aparatu za jonsko raspršivanje (JFC 1100E Ion Sputter JEOL). Tako pripremljeni uzorci su posmatrani i analizirani na skening-elektronskom mikroskopu (SEM) (JEOL JSM-5300). SEM ispitivanje je obavljeno na Institutu za biomedicinska istraživanja Medicinskog fakulteta u Nišu.

Ultrastruktura površinske korozije je ocenjivana modifikovanom skalom po Linsjuvanontu (Linsuwanont) i saradnicima [7]: ocena 3 je označavala kontinuiranu korozivnu površinu celog radnog dela instrumenta; ocena 2 - jasno ograničena korozivna polja; ocena 1 - pojedinačne korozivne jamice; ocena 0 bez korozivnih promena. Površina radnih delova instrumenata je posmatrana na tri nivoa (apeksni, srednji i koronarni). $\mathrm{Na}$ svakom nivou instrument je ocenjen odgovarajućom ocenom, a konačni skor predstavljao je srednju vrednost ocena sve tri trećine pojedinačno za svaki instrument i u okviru grupa.

Statistička analiza je urađena korišćenjem $\chi^{2}$-testa i Fišerovog (Fisher) testa egzaktnosti. Prag značajnosti je bio na vrednosti od $\mathrm{p}<0,05$.

\section{REZULTATI}

Ultrastrukturna analiza instrumenata je pokazala da su najintenzivnije korozivne promene nastale na Ni-Ti instrumentima nakon potapanja u rastvor $5,25 \% \mathrm{NaOCl}$. Veoma erodirana površina metala je zapažena duž čitavog radnog dela svih ispitivanih instrumenata ove grupe (ocena 3) (Tabela 2, Slike $1 \mathrm{i}$ 2). Osetljivost na $5,25 \% \mathrm{NaOCl}$ su pokazali i instrumenti od nerđajućeg čelika. Na površini radnih delova instrumenata uočene su naizmenično kontinuirane korozivne površine i ograničena polja površinske korozije, tako da je ukupan skor instrumenata ove grupe iznosio 2,33 (Tabela 2, Slika 3). Fišerov test egzaktnosti je pokazao statistički značajno veću osetljivost instrumenata od Ni-Ti u poređenju sa instrumentima od nerđajućeg čelika nakon potapanja u 5,25\% $\mathrm{NaOCl}(\mathrm{p}<0,001)$.

SEM analiza Ni-Ti instrumenata nakon potapanja u $0,2 \%$ CHX je pokazala ograničena korozivna polja i pojedinačne korozivne jamice na radnom delu instrumenta. Ukupan skor kod ove grupe instrumenata je bio 1,5 (Tabela 2, Slike 4 i 5). Nešto veću osetljivot na $0,2 \%$ CHX su pokazali instrumenti od nerđajućeg čelika, na čijoj površini je uočen veći broj ograničenih korozivnih polja u odnosu na pojedinačne korozivne jamice. Ukupan skor kod ove grupe instrumenata je bio 1,83 (Tabela 2, Slika 6). Međutim, Fišerov test egzaktnosti nije pokazao statistički značajnu razliku u osetljivosti između obe vrste instrumenata na $0,2 \% \operatorname{CHX}(\mathrm{p}=0,096)$.

Ultrastrukturnom analizom Ni-Ti instrumenata nakon potapanja u 17\% EDTA nisu uočena korozivna oštećenja na površinama radnih delova instrumenata, tako da je ovoj grupi dodeljena ocena 0 (Tabela 2, Slika 7). Korozivna oštećenja nisu uočena ni na površinama instrumenata od nerđajućeg čelika nakon potapanja u $17 \%$ EDTA, tako da je prosečan skor i kod ove grupe instrumenata bio 0 (Tabela 2, Slika 8).

Instrumenti od nikl-titanijuma i nerđajećeg čelika su pokazali razliku u osetljivosti na ispitivane rastvore za irigaciju. Instrumenti od Ni-Ti pokazali su značajno veću osetljivost na $5,25 \% \mathrm{NaOCl}$ u poređenju sa $0,2 \% \mathrm{CHX}$ ( $\chi^{2}$-test je pokazao da je ova razlika bila visoko statistički značajna; $p<0,001)$. Instrumenti od nerđajućeg čelika su takođe bili statistički značajno osetljiviji na potapanje u 5,25\% $\mathrm{NaOCl}$ u odnosu na $0,2 \% \mathrm{CHX}$ $(\mathrm{p}<0,05)$.

\section{DISKUSIJA}

Hemomehanička preparacija kanala korena je od suštinske važnosti za uspeh endodontskog lečenja i podrazumeva postupke čišćenja i oblikovanja endodontskim instrumentima i rastvorima za irigaciju. Mnogi rastvori se koriste kao intrakanalni irigansi: $\mathrm{NaOCl}$, vodonik-peroksid $\left(\mathrm{H}_{2} \mathrm{O}_{2}\right)$, limunska kiselina, EDTA, CHX, fiziološki rastvor i drugi [5]. Iako je primena irigansa tokom preparacije kanala neophodna, mnogi od njih svojim hemijskim i elektrohemijskim delovanjem mogu oštetiti strukturu instrumenata [8].

Elektrohemijske tehnike koje se zasnivaju na određivanju piting potencijala i gustine struje mogu precizno definisati osetljivost metala na rastvore u kojima se nalazi [9]. Analiza ultrastrukturnih karakteristika površine takođe ima važnu ulogu $\mathrm{u}$ određivanju korozivne osetljivosti ispitivanih endodontskih instrumenata u određenim rastvorima [10]. Korozija na mikroskopskom nivou je u direktnoj vezi sa slabljenjem strukture instrumenata i smanjenjem efikasnosti sečenja i otpornosti na lomljenje [9].

Na korozivno ponašanje legura nikl-titanijuma i nerđajućeg čelika, kao materijala od kojih se najčešće izrađuju endodontski instrumeni, mogu uticati brojni faktori. Stouks (Stokes) i saradnici [11] su ispitivali korozivni efekat novih, nekorišćenih $\mathrm{Ni}$-Ti instrumenata pet različitih proizvođača. Istraživanjem su uočene korodirane i nekorodirane turpije unutar istog pakovanja, čime je potvrđeno da na pojavu korozije može uticati proces proizvodnje instrumenata, odnosno kvalitet kontrole tog procesa. Negativan uticaj sterilizacije na pojavu korozije je takođe dokazan [10], a zastupljenost zaostalih proteinskih materija na površini endodontskih instrumenata može pojačati delovanje rastvora za irigaciju u rastvaranju metalne površine instrumenata [9].

Natrijum-hipohlorit $(\mathrm{NaOCl})$ je najčešće korišćen rastvor za irigaciju kanala korena u endodontskoj praksi. Koristi se $\mathrm{u}$ koncentracijama od 0,5\% do 6\% [12]. Ima širok antimikrobni spektar delovanja, a zbog sposobnosti rastvaranja organskog dela dentina koristi se za uklanjanje razmaznog sloja iz kanala korena, ali i kao sredstvo za natapanje instrumenata u procedurama čišćenja i sterilizacije posle kliničke upotrebe $[13,14]$. Međutim, $\mathrm{NaOCl}$ sadrži aktivne i agresivne jone $\mathrm{Cl}^{-}$koji u velikoj meri izazivaju korozivne jamice i slabljenje površinske strukture instrumenata [15]. Dokazano je da je NaOCl korozivan za mnoge metale i da je odgovoran za selektivno uklanjanje nikla iz legure $\mathrm{Ni}$-Ti [16]. Istraživanja su pokazala i merljivo oslobađanje titanijuma nakon potapanja Ni-Ti instrumenata u $\mathrm{NaOCl}$ u trajanju od 30 i 60 minuta [17]. Osetljivost endodontskih instrumenata 
od Ni-Ti i nerđajućeg čelika na potapanje u $\mathrm{NaOCl} \mathrm{je} \mathrm{dokazano}$ u brojnim studijama $[1,5,13]$. U istraživanju Stouksa i saradnika [11] korozija endodontskih instrumenata je vizuelno dokazana nakon potapanja u rastvor $\mathrm{NaOCl} u$ koncentraciji od 5,25\%. Uočena je značajna razlika između različitih proizvođača, ali nije bilo statistički značajne razlike između instrumenata od Ni-Ti i nerđajućeg čelika. Beruti (Berutti) i saradnici [4] su u svojoj studiji dokazali da su instrumenti potapani u $\mathrm{NaOCl}$ imali značajno smanjenu otpornost na lomljenje usled pojave ranog cikličnog zamora. Pojava neočekivane frakture ovih instrumenata bila je značajno veća u odnosu na instrumente kontrolne grupe. SEM analizom u oblasti preloma instrumenata uočena su brojna ograničena korozivna polja, jamice i pukotine. Međutim, uticaj jona $\mathrm{Cl}^{-}$i F- na koroziju kod Ni-Ti i nerđajućeg čelika je iskorišćena u studijama Amarala (Amaral) i saradnika [18] i Abuda (Aboud) i saradnika [19] radi elektrohemijskog rastvaranja i uklanjanja frakturisanih endodontskih instrumenata iz kanala korena. U ovom istraživanju uočene su snažno erodirane kontinuirane korozivne površine duž radnih delova instrumenata posle potapanja u $\mathrm{NaOCl}$ u koncentraciji od 5,25\%, što je u skladu s vrednostima piting potencijala dobijenim pri elektrohemijskom ispitivanju [6].

Hlorheksidin-glukonat (CHX) je sve češće upotrebljavano sredstvo za irigaciju kanala korena zbog svog produženog antimikrobnog dejstva, koje može trajati i do 12 nedelja [20]. Kao irigans se koristi u opsegu koncentracija od 0,1\% do $2 \%$. Međutim, podaci iz literature ukazuju na mogućnost pojave površinske korozije instrumenata nakon potapanja u CHX $[5,6]$. Korozivni potencijal CHX zavisi od njegove kisele reakcije ( $\mathrm{pH}$ 5,72 ) jer kisela sredina znatno povećava stepen korozije [21]. U ovom istraživanju su uočena korozivna oštećenja na površinama instrumenata od Ni-Ti i nerđajućeg čelika posle potapanja u $0,2 \%$ CHX. Ovakva vidljiva oštećenja u vidu ograničenih polja i jamica takođe mogu biti slabe tačke i mesta gde pri povećanom opterećenju instrumenta mogu nastati pukotine s izraženom tendencijom produbljivanja i pojave preloma [8].
Etilendiamintetrasirćetna kiselina (EDTA) je helaciono sredstvo koje se u endodonciji koristi u koncentracijama od 15\% do $17 \%$. Zbog svoje osobine rastvaranja neorganskog dela dentina koristi se kao lubrikant u preparaciji uskih i povijenih kanala, odnosno za uklanjanje neorganskog dela razmaznog sloja [22]. SEM analizom u ovom istraživanju nije uočen negativan uticaj EDTA na površinsku strukturu instrumenata od Ni-Ti i nerđajućeg čelika, što je u skladu s rezultatima elektrohemjiskog ispitivanja iz prethodnog istraživanja [6]. U istraživanju Fajada (Fayyad) i Marana (Mahran) [23] nije došlo do promene površinske hrapavosti endodontskih instrumenata nakon potapanja u 17-procentni rastvor EDTA. Prema mišljenju Rajnharda (Reinhard) i saradnika [24], EDTA ima sposobnost da štiti i pasivizira instrumente tako što formira komplekse s jonima metala pri $\mathrm{pH}$ vrednosti manjoj od 4 , čime stvara inhibitornu barijeru za oksidaciju i koroziju.

\section{ZAKLJUČAK}

Primena 5,25\% rastvora $\mathrm{NaOCl}$ i 0,2\% rastvora $\mathrm{CHX}$ za irigaciju kanala korena može izazavati ozbiljne korozivne promene na površini endodontskih instrumenata od Ni-Ti i nerđajućeg čelika. Primena rastvora EDTA u koncentraciji od $17 \%$ nije dovela do korozivnih promena kod ispitanih grupa instrumenata. Da bi se smanjio rizik od oštećenja instrumenata, preporučuje se da se instrumenti odmah po upotrebi očiste, kako bi se efikasno uklonio irigans s njihove površine.

\section{NAPOMENA}

Deo rezultata je saopšten u vidu poster-prezentacije na „Drugom regionalnom okruglom stolu: vatrostalstvo, procesna industrija i nanotehnologije Rosov PIN 2014“, koji je održan 23.i 24. oktobra 2014. godine na Fruškoj gori. 